\title{
Clinical Stage IVA Esophageal Squamous Cell Carcinoma AJCC v8
}

National Cancer Institute

\section{Source}

National Cancer Institute. Clinical Stage IVA Esophageal Squamous Cell Carcinoma A/CC

v8. NCl Thesaurus. Code C133452.

Stage IVA includes: (T4, N0-2, M0); (Any T, N3, M0). T4: Tumor invades adjacent structures. N0: No regional lymph node metastasis. N1: Tumor with metastasis in one or two regional lymph nodes. N2: T umor with metastasis in three to six regional lymph nodes. N3: T umor with metastasis in seven or more regional lymph nodes. M0: No distant metastasis. (AJCC 8th ed.) 